\title{
ACIDS OF POMEGRANATE PEEL
}

E. P. Nosacheva, Yu. B. Kerimov,

UDC 547.477 and T. N. Bikbulatova

The present paper gives the results of a chemical investigation of the peel of the fruit of Punica granatum L. (pomegranate), which is a waste material from the production of pomegranate juice.

The air-dried peel was exhaustively extracted with $70 \%$ ethanol. After the elimination of the solvent under vacuum, the aqueous residue was treated with chloroform to eliminate ballast substances and was then extracted with ether. On concentration of the ethereal extract, a precipitate deposited which was insoluble in hot water, ethanol, and ether and partially soluble in methanol. After purification, the substance had decomp. p. $355^{\circ} \mathrm{C}$.

Qualitative reactions [1], $\mathrm{R}_{f}$ value ( $\mathrm{FN}-15$ paper, $15 \%$ acetic acid system), and the IR spectrum of the substance were identical with those of ellagic acid.

On the basis of the results of a determination of the maximum intensities of the spots (SF-4a at $\lambda$ $440 \mathrm{~nm}$ ) revealed with a $1 \%$ solution of iron ammonium alum, it was established that the peel contains $0.55 \%$ of ellagic acid on the air-dry raw material. The ethereal extract was evaporated to dryness and chromatographed on Kapron with water. This gave gallic acid with $\mathrm{mp} 239^{\circ} \mathrm{C}$, which was identified from its $\mathrm{IR}$ spectrum and by chromatography with a marker. The quantative determination of the gallic acid $(0.09 \%$ on the absolutely dry raw material) was performed similarly.

\section{LITERATURE CITED}

1. T. Istirher and K. H. Lisken, Arch. Pharm., 295/67, 11, 823 (1962).

Mardakyan Tree Park, V. L. Komarov Institute of Botany, Academy of Sciences of the Azerbaidzhanian SSR. Translated from Khimiya Prirodnykh Soedinenii, No. 1, pp. 108-109, January-February, 1973. Original article submitted August 7, 1972.

01975 Consultants Bureau, a division of Plenum Publishing Corporation, 227 West 17th Street, New York, N. Y. 10011. No part of this publication may be reproduced, stored in a retrieval system, or transmitted, in any form or by any means, electronic, mechanical, photocopying, microfilming, recording or otherwise, without written permission of the publisher. A copy of this article is available from the publisher for $\$ 15.00$. 